to anything but these sensations and their laws. He must at least make believe that the act of will, for instance, is composed merely of sensations chiefly from the muscles, because only thereby is 'explanation' possible. In psychology, consequently, the truth is inevitably concealed, and some complex of sensations is substituted for the real mental process which we are to explain.

Few psychologists, I feel sure, would admit that this is a correct account of the psychological method. It sounds almost like a veiled apologia for some of the theories of both Professor Münsterberg and Professor James. They have each in their own way attempted to convince the world that certain 'complexes of sensations' were the whole truth in an act of will or an emotion; and the world has in the main steadily refused to be convinced. But now we are, as it were, called into the private office, and are told: "Of course, gentlemen, the complexes of sensations really are not the will or the emotion, but that is what we have to say they are if we are to be faithful to psychology."

But if in actually experiencing volition or emotion we clearly see that it is not a mere group of sensations, why should we be called upon gravely to declare in our psychologies the opposite? There is nothing in the rules of psychology to prevent our saying all the while that we are talking about the sensations characteristic of will or of emotion or of judgment-a mere part of the full process in consciousness. And if we can see, for instance, that a judgment has features additional to the mere sensations of muscular flexion or extension, I see no reason why, as psychologists, we should say, resignedly, that these other features are indescribable and beyond the pale of science. Quite apart from the question of values or of ideals, the experience itself reveals peculiarities of form that are quite definite and intelligible and communicable-has subject and predicate and the affirmative or negative connection, all of which are absent when the same sensations appear in a merely associative or temporal connection. Professor Münsterberg gives no sufficient reason why psychologists should hold that sensations are the only things in a mental process that are definite and describable and capable of helping to explain the process. As well might the physicist say that in his realm the bare atoms are all that he can take account of; when, in fact, time and distance are most necessary for any explanation that really explains. In other words, physical science has to take account both of the 'elements' and of their relationship or 'form.' And psychologists must do the same, noting not only such relations as are common to psychology and the physical sciences (time, for instance), but searching diligently whether there may not be some that are peculiar to our private mental life.

The general trend of the book, as can be readily seen, is to propose a more moderate estimate of psychology in general and of the laboratory work particularly. The later methods all come in for a drubbing: there is no quantitative work possible by psychological experiments; the brain physiologists can only borrow from psychology but give nothing in return; and child-study, with honorable exceptions, is something of a humbug. So that the general tone is a trifle disheartening to any of us who have faith in psychology and wish it well. As a counter-blast to those writings that magnify the office of psychology it may serve a good purpose. And since it is largely addressed to teachers, its chief benefit will undoubtedly be to remind them that a correct appreciation of the child and of the aims and ideals which are to be aroused in him is quite as important as a knowledge of the mechanism of the child's mind.

\section{UNIVERSITY OF CALIFoRNIA.}

George M. Stratton.

The Races of Man. An Outline of Anthropology and Ethnography. By J. DeNIKER, Sc.D. (Paris)-London. 1900. Walter Scott (American publishers, Charles Scribner's Sons). 611 pp., 176 illus., 2 maps.

The author of this handy text-book, forming Volume 37 in the Contemporary Science Series, is librarian of the Musée d'Histoire Naturelle in Paris. Moreover, he is a ripe specialist in human biology. Having, then, his own past experience as a guide, and being in touch with all the literature upon his theme, one is not surprised to find him interesting and instructive 
at every point. We may divide the volume into three parts :

Part I. Somatic characters, morphological and physiological, Chapters I.-III.

Part II. Ethnic characters, linguistic, industrial, sociological, Chapters IV.-VIII.

Part III. Classification of races and peoples, general and ethnic, IX. to close.

The first and the third parts are the best written, being in the author's special line. One is always eager to find out the point of view of a work like this, and we are not kept in suspense. 'Ethnic groups' are at once separated from 'somatological units' or 'races.' The latter are "theoretic types formed of an aggregation of physical characters combined in a certain way." These entities, theoretic conceptions, are exactly like species in zoology. Here is Deniker's list :

A. Woolly HaIr, Broad Nose.

Yellow, short, dolicho.

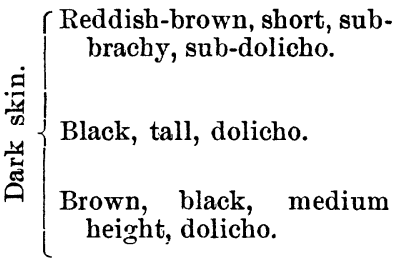

B. CuRly or Wavy Hair.

$\left\{\begin{array}{l}\text { Reddish-brown, leptorhine, } \\ \text { tall, dolicho. } \\ \text { Chocolate, brown, platyr- } \\ \text { hine, medium dolicho. } \\ \text { Brownish-black, short, dol- } \\ \text { icho. }\end{array}\right.$

5. Ethiopian.

6. Australian.

7. Dravidian (s. r. Platyrhine, leptorhine).

Tawny white, leptorhine, bra chy., nose hooked, etc.

8. Assyrioid.

C. Wavy, Dark Hair, Dark Eyes.

Brown skin, black hair, 9. Indo-Afghan. nose narrow, tall, dolicho., ellipitical face.

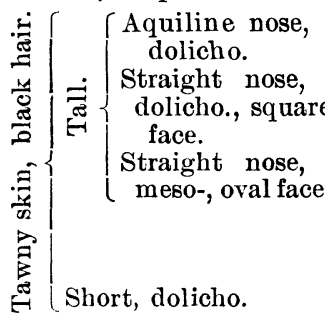

10. Arab or Semite.

11. Berber ( 4 subraces).

12. Littoral European.

13. Ibero-Ínsular.

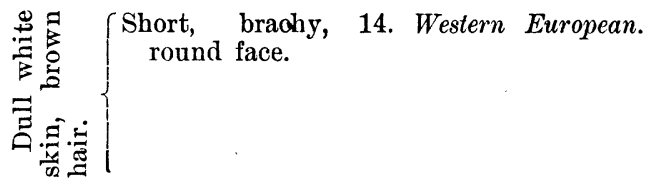

D. Fair, Wavy or Straight Hair, Light Eyes.

兽 $\begin{aligned} & \text { Wavy, reddish, } \\ & \text { hair, tall, dol- } \\ & \text { icho. } \\ & \text { Flaxen hair, } \\ & \text { straightish; short, } \\ & \text { sub-brachy. }\end{aligned}$

E. Straight or Wavy Hair, Dark Eyes.

Brown, hairy ; br oad concave nose, dolicho.

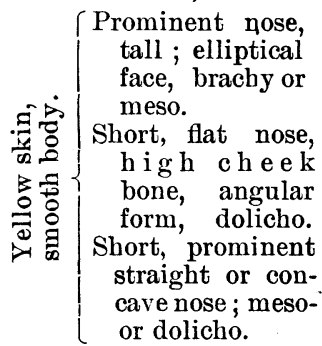

F. Straight Hair.

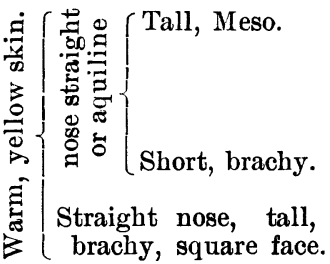

Brown-yellow, short, dol-

icho., round, flat face.

Turned up nose,
short, brachy.
Straight or concave,
nose, short, meso-.
or dolicho., high
cheek bone.
Straight nose, med-
ium height, hyper-
brachy.

Pale yellow, high-cheek

bone, Mongol eye,

slightly brachy.
16. Northern European.

17. Eastern European.

18. Ainu.

19. Polynesian.

20. Indonesian.

21. South American (s. r. Palaio-American, S. American).

22. North American (s. r. Atlantic, Pacific).

23. Central American.

24. Patagonian.

25. Eskimo.

26. Lapp.

27. Ugrian (s. r. Ugrian and Yeniseian).

28. Turkish or TurkoTartar.

29. Mongol (s. r.

Northern and Southern).
The succeeding table shows these races in their geographic contiguities.

The last chapters deal with the races by continents. Here the reader will find always references to the best special authorities where the author's statements are meagre. It is a pity that the Bureau of American Ethnology could 
not have read the proof of names for this continent. It is a little difficult for the English reader to detect 'Shahaptian' in 'Chahaptes.' The Trenton gravel controversy is an open question, and Dr. Deniker should have left it so on page 511. He does the cause no good, and his friends, Wilson and Boule, harm in setting them up as a court of last appeal.

\section{O. T. Mason.}

Malay Magic: Being an Introduction to the Folk and Popular Religion of the Malay Peninsula. By Walter William Skeat, with preface by CharLes Otto Blagdon. London, Macmillan \& Co. . 1900. Pp. xiv + 686, 7 figs., 28 plates. Price, $\$ 6.50$.

The folk mind, everywhere, stands in the same relation to truth that a celestial globe occupies with respect to the heavens. Here and there a star is in the right place, but all the rest is fanciful. But truth is exact agreement between what is and what is said, so, notwithstanding folk-lore is fancy, the beliefs are actually held, and we may have the truth about them. No other student within our acquaintance is better equipped for a work of this kind than Mr. Skeat.

Folk-lore, in this volume, is taken to mean the lore of the uncivilized races, containing in the germ, as yet undeveloped, the notions from which religion, law, medicine, philosophy, natural science and social customs are evolved. The operative side of living is excluded, but the regulative thoughts are folk-lore.

The word Malay incidentally includes with the people of that race in the peninsula others of the same blood near by, but the lore of the Chinese and other non-Malayan folk is excluded. The magician is the middle man between Malays and the spirit world. If he knows and reveals, he is Pawang; if he heals, he is Bomor. All that either does or says is classed by Mr. Skeats under magic. The Malays have had a series of religions, to wit, the aboriginal cult, which is a primitive sort of Brahmanism, with extensive pantheon, Buddhism and Mohammedanism. Now, it is easily comprehended, as Mr. Skeat shows, that these Pawangs and Bomors have nothing to do with Imams, Khatibs and Bilals of the mosques.
Also, if the reader is familiar with the present cult of the Latin American tribes, or of the Filippinos, he would not be shocked to see a long string of Malay invocations and magical rites performed before Hindu divinities, demons, ghosts and nature spirits, beginning with: "In the name of God, the Merciful, the Compassionate," and ending with: "There is no god but God, and Mohammed is His prophet."

In order to prepare the way for a better comprehension of Malay magic the author devotes the first fifty pages to native cosmogony, anthropogony, animism and notions about souls. Nearly as many pages discuss the world of spirits, the Malay pantheon and its relation to our world, as well as the class of men who act as go between from world to world.

The remainder of the work gives us the story of Malay beliefs and practices concerning fire, air, earth, water, and the life of man, in which the spirit world is involved, together with the description of paraphernalia the recital of formulæ, prayers, sacrifices, lustrations, fastings, divinations and witchcraft involved. Wisely, in the midst of so much jumbling of ethnic creeds and cults, the author abstains from attempts to analyze, and contents himself with recording in the most scrupulous manner the data on which philosophic discussion must be based. Pages 581-672 are devoted to Malay texts.

It would be unkind to point out little errors and omissions, since an enforced absence from England prevented the author from revising the proofs. The illustrations are not so good as those of Dr. Fewkes along the same line published by the Smithsonian Institution.

O. T. MASON.

Plant Structures. A second book of Botany. By John M. Coulter, A.M., Ph.D., Head of Department of Botany, University of Chicago. Twentieth Century Text-Books. D. Appleton \& Company. 1900. Pp. $x+348$. $12 \mathrm{mo}$, with 289 illustrations.

Several months ago the companion volume to the work now under review appeared, and was noticed in ScIENCE (December 8, 1899). That volume was designated as ' a first book of 